\title{
The Role of the Arts in Tagore's Concept of Schooling
}

IRENA LESAR ${ }^{1}$

$\approx$ The present article focuses particularly on the role and significance of the arts in the process of primary schooling in Tagore's school. He defined education as that which is one with life, and he believed that only education can give us real freedom. It is therefore essential that in the process of education we achieve the all-round development of the individual for harmonious adjustment to reality. The arts should be an essential part of life and of education, as it is only through the arts that it is possible to express one's experience and recognition of the harmonious connection between the universe, the individual reality and immortality, in addition to their being a source of pleasure. Only the arts (and nature as a teacher) enable the development of the entire personality, as well as the perception of reality and truth. Tagore thus understands the role of the arts in the life of the individual as a key factor in the formation of his/her personality, contributing to humanity.

Keywords: Shantiniketan, art education, education of the senses, education of the intellect, cultivation of feeling 


\section{Vloga umetnosti v Tagorejevem konceptu šolanja}

IRENA LESAR

$\approx$ Ta članek se osredinja predvsem na vlogo in pomembnost umetnosti $\mathrm{v}$ procesu vzgoje in izobraževanja $\mathrm{v}$ Tagorejevi šoli Shantiniketan. Tagore je vzgojno-izobraževalni proces opredelil kot eno z življenjem in je verjel, da nam lahko le vzgoja in izobraževanje dajeta resnično svobodo. Zato je ključno, da v vzgojno-izobraževalnem procesu dosežemo vsestranski razvoj posameznika za harmonično prilagoditev realnosti. Umetnost mora biti bistveni del življenja in vzgojno-izobraževalnega procesa, saj samo ta omogoča izražanje posameznikovih doživetij, predstavlja vir uživanja in ne nazadnje omogoča prepoznavanje harmonične povezanosti med vesoljem, individualno resničnostjo in nesmrtnostjo. Samo umetnost (in narava kot učitelj) omogoča razvoj celotne osebnosti pa tudi zaznavanje oz. dojemanje realnosti in resnice. Tagore torej razume vlogo umetnosti v življenju posameznika kot ključni dejavnik pri oblikovanju njegove osebnosti in kot tiste, ki prispevajo k človečnosti.

Ključne besede: Shantiniketan, umetnostna vzgoja, vzgoja čutil, vzgoja razuma, kultiviranje občutenja povezanosti 


\section{Introduction}

It is genuinely surprising how early Slovenian readers gained access to the works of Bengalese writer Rabindranath Tagore (7 May 1861 - 7 August 1941, also written Rabīndranātha Thākura), the first non-European winner of the Nobel Prize in Literature, as the first translation of his short prose The Crescent Moon (translated by Alojz Gradnik as Rastoči mesec) was available in Slovenian as early as 1917 . It is therefore even more surprising how little Tagore is known in Slovenia as the founder of his own special school Shantiniketan (literally abode (niketan) of peace (shanti)), which still operates in Bolpur, West Bengal; in the bibliographic system Cobiss, there is only one article in the Slovenian language focused on his school. It should be noted, however, that elsewhere in the world his solutions in the field of schooling have only come to prominence in recent times. As Jalan (1976) points out, his fame as a poet has eclipsed his exceptional contributions in literature to such a great extent that education and other aspects of his life have rarely received the attention and appreciation they deserve. At the same time, "his writings which are available in English versions do not fully represent his original work in Bengali. To a large extent, this was one of the reasons that, in his lifetime, Tagore's reputation in the Western world declined. English translations of his writings failed to give a complete picture of Tagore as an educator and social reconstructor. It seems worthwhile to explore other areas of Tagore's work and give them due attention" (Jalan, 1976, p. 2).

Tagore's ideas in the field of schooling are very interesting and are still relevant today despite their "age" (the first school commenced operation in 1901). In the present article, we will focus particularly on the role and significance of the arts in the process of primary schooling. Although this is one of the important features of Shantiniketan, analysts of Tagore's specific solutions devote little attention to it, instead perceiving it as almost self-evident, that is, as being a logical consequence of the founder himself, who was creatively active in numerous artistic fields during his lifetime. As K. M. O'Connell (2003) highlights in her presentation of Tagore, he "had written over twenty-five volumes of poetry, fifteen plays, ninety short stories, eleven novels, thirteen volumes of essays, initiated and edited various journals, prepared Bengali textbooks, kept up a correspondence involving thousands of letters, composed over two thousand songs; and - after the age of seventy - created more than two thousand pictures and sketches".

Understanding the role of the arts in Tagore's concept of education undoubtedly presupposes engaging with his basic points of departure in establishing his experimental school. In the present article, we will therefore dwell somewhat on his demands regarding the quality of schooling and the role of the 
arts in the process of education. Although this represents an extremely narrow sector of Tagore's overall creativity in the field of education (which includes, for example, adult education of the rural population, national reconstruction with the village as the centre, the advocation of coeducation, eco-pedagogy, etc.), it is particularly relevant today, when most European countries are reflecting on how to reform school systems in order to achieve the objectives of the Lisbon Strategy or to improve results in international assessments (e.g., PISA, PIRLS, etc.). However, these processes often focus only on the pragmatic aspect of acquiring knowledge, and therefore justify arts education primarily with the so-called instrumental benefits evident on the private (improved test results, learning skills and self-efficacy, etc.) and public (development of social capital, economic growth, etc.) levels (Forrest, 2011; McCarthy, Ondaatje, Zarakas, \& Brooks, 2004; Winner, Goldstein, \& Vincent-Lancrin, 2013). Through familiarisation with Tagore's ideas about education, we can also assess what the role of school is or should be in modern society.

\section{A briefly summary of Tagore's life and his work in the field of education}

Rabindranath Tagore was born in 1861 into a prominent Calcutta family known for its socio-religious and cultural innovations during the $19^{\text {th }}$ Bengal Renaissance. His grandfather Dwarkanath was involved in supporting medical facilities, educational institutions and the arts, and he fought for religious and social reform and the establishment of a free press. His father was also a leader in social and religious reform, and encouraged multicultural exchange in the family mansion Jorasanko (Jalan, 1976; O’Connell, 2003; Tagore, 2012). Tagore remembered this period as follows: "Fortunately for me I was brought up in a family where literature, music and art had become instinctive. My brothers and cousins lived in the freedom of ideas, and most of them had natural artistic powers. Nourished in these surroundings, I began to think early and to dream and to put my thoughts into expression. In religion and social ideals our family was free from all convention, being ostracized by society owing to our secession from orthodox beliefs and customs. This made us fearless in our freedom of mind, and we tried experiments in all departments of life. This was the education I had in my early days, freedom and joy in the exercise of my mental and artistic faculties. And because this made my mind fully alive to grow in its natural environment of nutrition, therefore the grinding of school system became so extremely intolerable to me" (Tagore, 1917, pp. 169-170). Given this description, it comes as no surprise that, after brief exposure to several schools, 
Tagore refused to attend school. The only university degrees he ever received were honorary degrees bestowed late in life (O'Connell, 2003).

Tagore grew up in a house where all of the surging tides of the Indian Renaissance flowed through his daily life. In Bengal, this found expression in three great movements: religious, literary and national (Jalan, 1976). His experiences at Jorasanko provided him with a lifelong conviction about the importance of freedom in education and the importance of the arts for developing empathy and sensitivity, as well as the necessity for an intimate relationship with one's cultural and natural environment. In participating in the cosmopolitan activities of the family, he came to reject narrowness in general, and in particular any form of narrowness that separated one human being from another. He viewed education as a vehicle for appreciating the richest aspects of other cultures while maintaining one's own cultural specificity (O'Connell, 2003). As Tagore himself wrote: "I was brought up in an atmosphere of aspiration, aspiration for the expansion of the human spirit. We in our home sought freedom of power in our language, freedom of imagination in our literature, freedom of soul in our religious creeds and that of mind in our social environment. Such an opportunity has given me confidence in the power of education which is one with life and only which can give us real freedom, the highest that is claimed for man, his freedom of moral communion in the human world..." (Tagore, 1929, pp. 73-74, in O'Connell, 2003).

Even though Tagore did not have an academic degree in education, he was a great educator of his time. He not only advocated changes in education but also practised them in his school at Shantiniketan, which was founded in 1901 under the name Brahmacharyasram and was later changed to Brahmavidyalaya and finally to simply the Shantiniketan School. The school was expanded and, in 1921, the International University Visva-Bharati was formally inaugurated. In 1922, the rural welfare department of Visva-Bharati was formally opened in Surul with the name Sriniketan (the word "Sri" contains the idea of prosperity). Like the other departments of Visva-Bharati, Sriniketan grew slowly from small beginnings into a major centre of rural reconstruction and village education (Jalan, 1976). Many famous people have acquired knowledge in Tagore's schools, including Indira Gandhi, Gayatri Devi, Abdul Ghani Khan and Amartya Sen (Visva Bharati Alumni, 2015).

\section{Tagore on education}

Although Tagore was not an educationist in the strict academic sense and did not talk about the aim of education in a well-formulated logical way 
(Jalan, 1976; Singh \& Singh Rawat, 2013), his various essays contain a well-integrated view of life and the role of education in it. As Elmhirst writes (1961), Tagore's reflections on education were strongly marked by his first meeting with villagers in 1890, with their sufferings and their many problems related to cultivation, credit and marketing. At the beginning of the $20^{\text {th }}$ century, when he was nearly 40 years old and was faced with the question of his own son's education, Tagore moved with his family from Calcutta to Shantiniketan, in order to found the school in which he expected to realise his ideas:

- $\quad$ to save children from some of the frustrations that he had suffered as a boy in the name of education;

- $\quad$ to cultivate and develop the arts of life: poetry, song, drama, movement in dance and design;

- to discover whether or not the Bengal villager could learn to stand on his/her own two feet and begin to solve at least some of his/her many problems for him/herself (Elmhirst, 1961, p. 18).

Tagore's deepening experience in relating to man and nature gave rise to his two most persistent drives in life: to bring joy and creativity to urban education along with alternative values for a sustainable future, and to bring scientific education and self-reliance to the rural people (Das Gupta, 2015).

Thanks to authors who understand Bengali and have undertaken exceptional research of his numerous writings (Das Gupta, 2015; Jalan, 1976; Nath Pan \& Mete, 2007; Singh \& Singh Rawat, 2013), we can see that Tagore's conception of education in the life of the individual and in society is specific, and that it is necessary to have at least a basic understanding of his philosophy of education in order to understand the role of the arts in the process of education. Although one can find numerous educational goals in his texts (such as education for international understanding and universal brotherhoods, education for aiding in the process of rural reconstruction), and although he stresses that it is necessary to respect certain demands in the process of education (such as encouraging the correlation between man and nature, blending the ideas of the East and West, the mother tongue as the medium of instruction, the rejection of book-centred education, practical and real teaching), in the continuation we will only focus on those goals and demands that enable us a more complex understanding of the role of the arts in the Shantiniketan School.

The ultimate aim of education - which did not emerge from the outside world but from Tagore's own experience, practice and experiments - should be the all round development of the individual for a harmonious adjustment to reality. Tagore regretted that "education of sympathy was not only systematically ignored in schools, but was severely repressed, because we may become 
powerful by knowledge, but we attain fullness by sympathy. The highest education is that which does not merely give us information but makes our life in harmony with all existence" (Tagore, 1917, p. 142). Harmony with all existence can only be achieved when all of the faculties of the individual - intellectual, physical, moral, social and aesthetic - have been developed to the highest level of perfection.

In Tagore's philosophy of education, aesthetic development is just as important as intellectual development, if not more so, and music, literature, visual art, dance and drama were given great prominence in the daily life of the school. Students should take an active part in these finer aspects of human life, as they are essential to enrich the soul.

Tagore also placed great emphasis on the intellectual development of the child, the cultivation of the intellect in order to counterbalance emotional immaturity and instability, where it exists. However, he believed that this intellectual cultivation (e.g., the development of the imagination, creative free thinking, constant curiosity and alertness of the mind) could not be gained merely by reading books. Tagore was aware that "since childhood, instead of putting all the burden on the memory, the power of thinking, and the power of imagination should also be given opportunities for free exercise" (Tagore, 1351 B.S., p. 12, in Jalan, 1976, p. 42).

Tagore placed a great deal of importance on physical development, as evidenced by the fact that yoga, games and sports are prescribed in Shantiniketan as an integral part of the education system. "It is a function of the body, not merely to carry out vital actions so that we may live and move, but so that we may express, and not with the face alone, but with the legs, the arms and the hands. All our limbs have their own power to express. /.../ We often take a brisk walk when we are agitated, because thought needs bodily expression if it is to perform its work freely and fully. Children must dance, they must be restless, when they think, the body becomes restless and ripples with a variety of movement that helps to keep their muscles in harmony with the mind" (Tagore, 1961, p. 102). Movement, which we can also recognise in his demand for "the peripatetic" or mobile school, is important because it not only facilitates learning many things through direct observation but also keeps our awakened mental faculties constantly alert and receptive through contact with ever-varying scenes and objects (Jalan, 1976).

In order to achieve an integral development of the human personality, moral and spiritual education are more important than bookish knowledge. There must be adequate provision for the development of selfless activities, cooperation, and love of empathy and sharing among students in educational 
institutions. Tagore emphasised the importance of discipline in a moral life, and real discipline means the protection of raw, natural impulses from unhealthy excitement and from growing in undesirable directions. Tagore's moral and spiritual aims in education were varied in nature. He advocated the power of self-determination, the ideal of peace and tranquillity, and the virtue of liberation of the self from all kinds of slavery, and his educational institutions supported these aims. As he himself said, "The character of good education is that it does not overpower man; it emancipates him" (Tagore, 1351 B.S., p. 62, in Jalan, 1976, p. 44).

Tagore stated that only through freedom man can attain his fullness of growth. He postulated three kinds of freedom: freedom of mind, freedom of heart and freedom of will. Freedom of mind is contrasted with the adult system of concentration of mind, and a child can only grow fully when he/she is given freedom to express him/herself, to explore the world on his/her own. Tagore interpreted freedom of heart as unrestricted human relationships. In school, teachers should act as a substitute for the mother in providing freedom of love to the children through understanding, sympathy and free companionship. Finally, freedom of will, or the free activity of the soul, consists of creating one's own world. The way to realise this ideal is to invite pupils to participate in the growth and development of the school. Accordingly, Tagore gave students free reign to develop their interest in any field they liked (Jalan, 1976).

Tagore believed that nature is the pupil's best teacher. Based on his experiences, Tagore argued that education should seek to develop sensitivity in the child through the direct experience of nature when her/his consciousness is at its freshest level. He recognised early childhood as the most critical time for developing empathy and the ability to connect with one's surroundings. It is nature that will be the guiding force to inculcate the mind of the student with the spirit of learning, so that he/she will pursue the education he/she likes; it is nature that will shape his/her behaviour and character (O'Connell, 2010). It is for this reason that Tagore was convinced that, in their early development, children should grow up in an environment surrounded by nature and not encircled by numerous modern acquisitions, which is why some observers reproached him for advocating bringing up children in poverty (Tagore, 1917).

Spiritualism is the essence of humanism. Manifestation of the personality depends upon the self-realisation and spiritual knowledge of the individual. Religion has an important place in education, but, for Tagore, this did not involve the formal teaching of a particular religious dogma. True religiousness, he stated, is as natural as respiration; it is as much a vital part of our being as breathing. He regarded religious training as a spirit, an inspiration, pervading 
every aspect of human life, affirming its relationship with the highest of values and providing man with a sense of kinship with the Real. If education fails to cultivate the quality of human understanding and strengthen the sense of human unity, then it is considered superficial and misguided (Jalan, 1976). According to Tagore, Brahma, the supreme soul, manifests himself through men and other creatures. Since Brahma is the source of all human beings and all creatures, they are all equal. Tagore therefore said, "Service to man is service to God" (Singh \& Singh Rawat, 2013, p. 207). All human beings should develop social relationships and empathy for their fellow man from the beginning of their lives. Education aims at the individual personality as well as at the social characteristics that enable one to live as a worthy being.

Although each of the key characteristics of Tagore's philosophy of education would need to be analysed in more detail, the brief overview presented above will, in the continuation, enable a deeper understanding of the role of the arts in this philosophy, which are given a special place in Tagore's life and in his school.

\section{Why are the arts so important to Tagore?}

In his work Personality (1917), Tagore devotes the first chapter to the question What is art? Like many other authors (Forrest, 2011), Tagore faces difficulties in defining art, "which has a life growth" (Tagore, 1917, p. 15), and that would mean "limiting one's own vision in order to see clear" (Tagore, 1917, p. 15). In his reflections, he therefore decided: "I shall not define Art, but question myself about the reason of its existence, and try to find out whether it owes its origin to some social purpose, or to the need of catering for our aesthetic enjoyment, or whether it has come out of some impulse of expression, which is the impulse of our being itself" (Tagore, 1917, p. 16). From his list of possible reasons for the existence of the arts, as well as from other texts, it is clear that Tagore does not emphasise the instrumental benefits brought by art, but rather remains within the framework of private intrinsic benefits, such as captivation, pleasure, an expanded capacity for empathy, and cognitive growth (McCarthy et al., 2004). This finding comes as no surprise if we consider the key emphases of his philosophy of education presented in the previous section, which make it entirely clear that the goals of education are focused only on the complete development of the individual and the encouragement of his/her emancipation.

Despite deciding not to define art, Tagore establishes its specific characteristics in comparison with science: "The world of science is not a world of reality, it is an abstract world of force. We can use it by the help of our intellect 
but cannot realize it by the help of our personality. It is like a swarm of mechanics who, though producing things for ourselves as personal beings, are mere shadows to us. But there is another world which is real to us. We see it, feel it; we deal with it with all our emotions. Its mystery is endless because we cannot analyse it or measure it. We can but say, 'Here you are"' (Tagore, 1917, p. 12). In the continuation, he emphasises that "our scientific world is our world of reasoning. It has its greatness and uses and attractions. We are ready to pay the homage due to it. But when it claims to have discovered the real world for us and laughs at the worlds of all simpleminded men, then we must say it is like a general grown intoxicated of his power, usurping the throne of his king. The reality of the world belongs to the personality of man and not to reasoning, which is useful and great but which is not the man himself. /.../ Science does it by eliminating from its field of research the personality of creation and fixing its attention only upon the medium of creation" (Tagore, 1917, pp. 70, 72).

In this regard, it should be emphasised that Tagore initially distinguished between education of the senses (indriyer siksa) and education of the intellect (jnaner siksa). He then adds "cultivation of feeling" (bodher tapasya/sadhana), which involves an expansion of sympathy in kinship with all existence, that is, the realisation of man's bond of union with the universe through the spirit, the soul and the deeper intuition of feeling (Jalan, 1976; O'Connell, 2010). Taking into account the demand that, in education, it is necessary to cultivate feeling and the aforementioned moral and spiritual education, it is possible to understand the following reflection: "... our consciousness of the world, merely as the sum total of things that exist, and as governed by laws, is imperfect. But it is perfect when our consciousness realises all things as spiritually one with it, and therefore capable of giving us joy. For us the highest purpose of this world is not merely living in it, knowing it and making use of it, but realising our own selves in it through expansion of sympathy; not alienating ourselves from it and dominating it, but comprehending and uniting it with ourselves in perfect union" (“The Religion of the Forest” pp. 48-49, in O'Connell, 2010, p. 69). Tagore therefore emphasises that we must be particularly aware of our own infiniteness, which is reflected in our aspiration, enjoyment and sacrifice. "This infinite side of man must have its revealments in some symbols which have the elements of immortality. There it naturally seeks perfection. Therefore it refuses all that is flimsy and feeble and incongruous. It builds for its dwelling a paradise, where only those materials are used that have transcended the earth's mortality" (Tagore, 1917, pp. 43-44). From this, we can determine that, for Tagore, the arts are essential for the cultivation of feeling and experience, as well as for the expression of man's bond of union with the universe and his 
infinite side. He believes that the role of artists is to discover the unique, the individual, which is at the heart of the universal. Unlike a botanist, for example, who on viewing a tree will attempt to classify and analyse it, the artist views it in its uniqueness, "Not through the peculiarity which is the discord of the unique, but through the personality which is harmony. Therefore he has to find out the inner concordance of that one thing with its outer surroundings of all things" (Tagore, 1917, p. 35). We can conclude that Tagore located the distinction between science and the arts in contrasting the general with the unique (Strunkel, 2003), and in the observation that the world of facts, which is characteristic of science, does not coincide with our world of experiences and expression.

In the continuation, Tagore compares man with other living beings and determines that "only man knows himself, because his impulse of knowledge comes back to him in its excess. He feels more intensely his personality than other creatures, because his power of feeling is more than can be exhausted by his objects. This efflux of the consciousness of his personality requires an outpour of expression. Therefore, in Art, man reveals himself and not his objects. His objects have their place in books of information and science, where he has completely to conceal himself" (Tagore, 1917, pp. 21-22). Tagore viewed the world of experience as the relationship of human consciousness with his object, and maintained that poets evoke a mutually dependent reality at the moment of inspiration. He did not believe that the world exists as an object independent of a perceiving subject, but he also did not accept that individual consciousness creates existence from itself (Stukel, 2003).

Tagore also emphasises that "In everyday life, when mostly we are moved by our habits, we are economical in our expression; for then our soulconsciousness is at its low level, - it has just volume enough to glide on in accustomed grooves. But when our heart is fully awakened in love, or in other great emotions, our personality is in its flood-tide. Then it feels the longing to express itself for the very sake of expression. Then comes Art, and we forget the claims of necessity, the thrift of usefulness, - the spires of our temples try to kiss the stars and the notes of our music to fathom the depth of the ineffable. /... / Man's energies, running on two parallel lines, - that of utility and of selfexpression - tend to meet and mingle" (Tagore, 1917, p. 27).

Tagore also engages with the question as to whether the central goal of the arts is the production of beauty. "As a consequence of this, we have often heard it argued whether manner, rather than matter, is the essential element in art. Such arguments become endless, like pouring water into a vessel whose bottom has been taken away. These discussions owe their origin to the idea that beauty is the object of art, and, because mere matter cannot have the property 
of beauty, it becomes a question whether manner is not the principal factor in art. But the truth is, analytical treatment will not help us in discovering what is the vital point in art. For the true principle of art is the principle of unity, which cannot be analysed" (Tagore, 1917, pp. 30-31). A similar conclusion was reached by M. Forrest (2011, p. 69), who, in her reflections Justifying the Arts: The Value of Illuminating Failures, writes: "The ineffable quality of engagement that one experiences with a work of art defies causal forms of explanation. It provokes something that is unutterable yet must be uttered and accepted. The work of art provokes a performative paradox. Though we may offer causal explanations, they do not touch that which is characteristic of art; that which provokes us to offer 'peculiar kinds of comparisons' and the 'grouping together of certain cases"'

Reading Tagore's reflections on the role of the arts in the life of the individual and society leads to the conclusion that the arts should be an essential part of life and therefore also an essential part of education, as it is only through the arts that it is possible to express one's experience and recognition of the harmonious connection between the universe, the individual reality and immortality, in addition to their being a source of pleasure. A human being is not only defined by the ability of reasoning; therefore, only the arts (and nature as a teacher) enable the development of the entire personality, as well as the perception of reality and truth. "This building of his true world, - the living world of truth and beauty, - is the function of Art" (Tagore, 1917, p. 44). Tagore thus understands the role of the arts in the life of the individual as a key factor in the formation of his/her personality, contributing to humanity. "Man's education," he categorically affirms, "aims at keeping alive to the last moment of life that infinite aspiration which is necessary for developing into full manhood. To attain full manhood is the ultimate end of education; everything else is subordinate to it" (Tagore, 1326 B.S., in Jalan, 1976, p. 41), and it is within the framework of the arts that Tagore emphasises the importance of blending the ideas of the East and the West.

\section{The role of the arts in Shantiniketan}

On recognising the importance that Tagore's philosophy of education places on the role of the arts in the life of the individual and society, one would expect his curriculum to place the greatest emphasis on a diverse range of artistic genres. This is, however, not the case, as the curriculum included "only" Bengali, Sanskrit, English, arithmetic, history, geography and science (Jalan, 1976, p. 62). Nonetheless, as emphasised by Mathew Pritchard (2014), who 
studied the Rabindrasangit (the songs composed by Tagore) from 2009 to 2010 at the Sangit Bhavan or music department of the Visva-Bharati University in Shantiniketan, "although music and the arts were not part of the curriculum as such, they (along with observation of Nature, and games) formed part of the leisure hour after lessons were over. Rabindranath was in one of his most important creative phases in the 1900 s and shared the results with the students. They worked to put on several of his plays, with regular lessons being deserted or cancelled as the school gathered around the famous open rehearsals leading up to the first performance. (This is still a feature of life at Sangit Bhavan and helps to create its particular atmosphere; though I can confirm it has its frustrating side when one is trying to pursue a regular course of study!)" (Pritchard, 2014, p. 105).

At the end of afternoon lessons (around $4.30 \mathrm{pm}$ ), before dinner, there is free time that the students enjoy in various ways. There are outdoor games organised for boys and girls, while some students go on long walking excursions with their teachers, spending the whole day in the open air, singing and playing games. Inspired by Tagore's life and teaching, some of the older and stronger boys go to the neighbouring villages to undertake a well-organised programme of social service, holding evening schools for (poor) villagers, organising their sports and amusements, teaching them handicrafts and helping them in many other ways with their essential tasks (Jalan, 1976, pp. 93-94).

When the evening meal is over, the students have time for entertainment such as storytelling, singing, a circus performance or enacting a play composed by the students themselves, to which the masters are invited. Evening study is forbidden for all boys and girls, with the exception of older students who need extra hours of work (Jalan, 1976, p. 95). When asked why he planned it this way, Tagore answered, "Books tell us that the discovery of fire was one of the biggest discoveries of man. I do not wish to dispute this. But I cannot help feeling how fortunate the little birds are that their parents cannot light lamps of an evening. They have their language lessons early in the morning and you must have noticed how gleefully they learn them" (Tagore, 1917, pp. 39-40).

From this description, we can conclude that, although the arts are not present within the framework of the regular instruction of the Shantiniketan Primary School, they are strongly embedded in leisure activities and in the everyday lives of the students, and therefore have a strong influence on them. In this regard, the question arises as to whether the students recite, perform, sing and stage their own creations and the works of Tagore, or whether they are also familiar with other artworks from India and further afield. From one of Tagore's letters, we can gather that he always sought to invite a diverse range of first-rate 
artists to the school, not only from India but also from the Far East and Europe (Tagore, 2012, p. 168). In view of the fact that, in his childhood at home, Tagore had an opportunity to meet and associate with superb artists from diverse fields of culture, it comes as no surprise that he made great efforts to offer this experience to his students as often as possible. This practice is also in accordance with his goals of schooling - education for international understanding and universal brotherhoods - which he perhaps achieved only through becoming familiar with and admiring the cultural creations of other nations.

In this regard, Gall (2015) points out that "Tagore was striving for a form of community situated between the extremes of urban oversophisticated 'development' and a life submerged in rural primitive economic preoccupation with meeting basic existential needs. Both situations constrict people's freedom and culture in different ways. Nevertheless, with regard to working out the tensions between art and mundanity, aspects of Tagore aesthetics were problematic regardless of how insightful they otherwise were: specifically, the separation of the art/leisure/culture realm from the mundane/utilitarian/work realm" (Gall, 2015, p. 134). It has to be admitted that Tagore's Sanskrit formula, projected discursively and institutionally (Shriniketan is a school separate from Shantiniketan, devoted to poor children from the neighbouring villages), "regarded mundanity as something we have to live with relieved by art, not as something which could be transformed by it" (Gall, 2015, pp. 135-136).

In the continuation, Gall emphasises that Nandalal Bose (1882-1966), who was responsible for the task of directing the art programme in Kala Bhavana, succeeded in realising a different view of art in her pedagogical work, one that was not divorced from the mundane (Gall, 2015, p. 136). As Gall determines, one can gather from the texts and work of N. Bose that "there is a conviction that the divine, the most sublime, inhabits the mundane as much as the extraordinary, the secular as much as the sacred. /.../ Crucial to the transformation/translation of mundane materials, mechanical devices, skill and techniques, subject matter and themes, regardless of scale, was the practising human subject. The subject's attunement with truth(s) in his or her object emotionally, intellectually, physically - distinguished the subject's activity, (art) practice and resulting (art) objects; marking them as more or less carriers of freedom or bondage, supra-personal meaning and delight (Ananda), or ego circumscribed and limited if not frustrated" (Gall, 2015, p. 138). Gall concludes his analysis with Tagore's observation that the overly strong connection between educational institutions and capitalist culture prevents alternative visions. This is why he established Visva-Bharati, where not only was it possible to imagine "work-survival-success" in a healthy relation to "art-leisure-pleasure", but 
where Nandalal Bose, together with her artists/teachers, "could conceive the possibility of transforming the everyday and mundane. Their vision needs to be built on and advanced, their insight globalised" (Gall, 2015, p. 143).

\section{Conclusion}

Tagore conceived his experimental school in Shantiniketan on the basis of his own bad experiences with various schools - despite the fact that he did not complete any of these schools and therefore did not gain a formal level of education - as well as on his recognition of how strongly the schools of the time were influenced by the ruling elite, who sought to preserve the prevailing relationships of social power. However, more than the preservation of the social class system and the power of the elite, Tagore was probably more concerned about the influence of the operation of the schools on the developing human being. The schools were primarily focused on the development of memory and reason, and with their scientific methodology they convinced growing children that only this kind of analytical thinking and functioning in the world was of value, thus completely overlooking the wholeness of life and the genuine purpose of education.

Tagore defined education as that which is one with life, and he believed that only education can give us real freedom (freedom of mind, freedom of heart and freedom of will). It is therefore essential that in the process of education we achieve the all-round development of the individual for harmonious adjustment to reality. In creating the school, Tagore drew from his own deep experience of connection with nature (in the early period, the children therefore spend most of their time in the natural environment), and from the presence of the eternal Divine Spirit in all creation (the authenticity of the place lay in its respect for the "sacrament of co-existence" (Ghosh, 2012, p. 27) and in the idea that we can find our meaning and fulfilment relationally, in our kinship with all that is), as well as from the education he had experienced in his own family (the necessity to create a rich cultural environment).

Not only do pupils become familiar with various artistic genres in their free time, the arts enable them to experience and express their individual reality, harmony with all existence, immortality and a unique bond with the Universe. As well as bringing joy, this kind of experience encourages the cultivation of feelings and provides practice in freedom of 'mind, heart and will'. Thus the arts facilitate not only aesthetic development, but also intellectual, physical and moral development. It is interesting that Tagore completely rejected education about the arts, instead advocating education through the arts. His success lay 
in the fact that he did not try to directly control the ideas, feelings and values of the children, but imaginatively designed an environment and a programme of activities and experiences that evoked the desired responses. "I tried my best, to develop in the children of my school the freshness of their feeling for nature, a sensitiveness of soul in their relationship with their human surroundings with the help of literature, festive ceremonials and also the religious teaching which enjoins us to come to the nearer presence of the world through the soul, thus to gain it more than can be measured" (Tagore, 1946, p. 9, in Jalan, 1976, p. 102). We could say that education and culture are one in the same thing, they are an ongoing process, and a process quite open to processes outside the school walls, in the sense that Tagore's understanding of the role of the arts in the process of education is very close to the Humboldtian tradition of Bildung (Pritchard, 2014, p. 111).

Tagore's philosophy of education, including art education, can be described as Romantic and idealist in orientation (Ghosh, 2012; Pritchard, 2014). In his conception of school and his philosophy of education, many contemporary authors nonetheless recognise a source of inspiration in justifying the necessity of including the arts in education, not only in order to realise intrinsic benefits, but also due to contemporary challenges within the framework of citizenship education (Nussbaum, 2006), the demand for the more efficient development of students' creativity (O'Connell, 2010), and greater ecological awareness of young people (Ghosh, 2012; O’Connell, 2010). There is no doubt that Tagore's reflections also present contemporary pedagogues with numerous challenges, particularly with regard to seeking a paradigm for the effects of this kind of teaching and regime in school on developing individuals. For those dealing with the question of the role of school in modern societies, Tagore's concept of education represents a support in defining the school not only as an "ideological apparatus of the (European) economy" but as a cultural institution in which science and art have an equivalent role, and in which not only the instrumental benefits are highlighted, but also the moral educational benefits.

\section{References}

Das Gupta, U. (2015). Rabindranath Tagore (1861-1941) a Biographical Sketch. Retrieved 15.03.2015 from http://www.parabaas.com/rabindranath/articles/pTagore_Biography.html

Elmhirst, L. K. (1961). The Foundation of Sriniketan. In R. Tagore \& L. K. Elmhirst (Eds.),

Rabindranath Tagore Pioneer in Education: Essays and Exchanges between Rabindranath Tagore and L. K. Elmhirst (pp. 18-43). London: John Murray.

Forrest, M. (2011). Justifying the Arts: The Value of Illuminating Failures. Journal of Philosophy of 
Education, 45(1), 59-73.

Gall, D. A. (2015). A Dialectic of Disinterested and Immersive Aesthetics: Santiniketan Art Education and Labour Translated. International Journal of Art \& Design Education, 34, 132-144. doi: 10.1111/ jade. 01769

McCarthy, K. F., Ondaatje, E. H., Zarakas, L., \& Brooks, A. (2004). Gifts of the Muse. Reframing the Debate About the Benefits of the Arts. Santa Monica: RAND Corporation.

Nussbaum, M. C. (2006). Education and Democratic Citizenship: Capabilities and Quality Education. Journal of Human Development, 7(3), 385-395.

O'Connell, K. M. (2003). 'Rabindranath Tagore on education'. The encyclopaedia of informal education. Retrieved 15.03.2015 from: http://infed.org/mobi/rabindranath-tagore-on-education/ Pritchard, M. (2014). A poem in a medium not of words: Music, dance and arts education in Rabindranath Tagore's Santiniketan. Arts \& Humanities in Higher Education, 13(1-2), 101-114. DOI: $10.1177 / 1474022213491344$

Jalan, R. V. (1976). Tagore - his educational theory and practice and its impact on Indian education [A dissertation presented to the graduate council of The university of Florida in partial fulfillment of the requirements for the degree of Doctor of philosophy]. University of Florida. Retrieved 25.07.2012 from https://archive.org/details/tagorehiseducatioojala

Ghosh, R. (2012) A Poet's School: Rabindranath Tagore and the Politics of Aesthetic Education, South Asia. Journal of South Asian Studies, 35(1), 13- 32, DOI: 10.1080/00856401.2012.648900 Singh, R., \& Singh Rawat, S. (2013). Rabindranath tagore's contribution in education. VSRD International Journal of Technical \& Non-Technical Research, IV(VIII), 201-208.

Strunkel, K. R. (2003) Rabindranath Tagore and the Aesthetics of Postmodernism. International Journal of Politics, Culture and Society, 17(2), 237-259.

Tagore, R. (1917). The Personality. New York: Macmillian Company.

Tagore, R. (1961). A Poet's School. In R. Tagore \& L. K. Elmhirst (Eds.), Rabindranath Tagore Pioneer in Education: Essays and Exchanges between Rabindranath Tagore and L. K. Elmhirst (pp. 44-65).

London: John Murray.

Tagore, R. (1961). The Art of Movement in Education. In R. Tagore \& L. K. Elmhirst (Eds.), Rabindranath Tagore Pioneer in Education: Essays and Exchanges between Rabindranath Tagore and L. K. Elmhirst (pp. 101-111). London: John Murray.

Tagore, R. (2012). Moje življenje, o njem vam pripovedujem (uredila in uvod napisala Uma Das Gupta). Ljubljana: Modrijan.

Visva Bharati Alumni. (2015). Retrieved 15.03.2015 from http://visva-bharati.ac.in/Alumuni/ Contents/alumuni_contents.htm?f=../Contents/famous_alumni.htm

Winner, E., Goldstein, T., \& Vincent-Lancrin, S. (2013). Art for Art's Sake? Overview. OECD Publishing. Retrieved 20.11.2014 from http://www.oecd.org/edu/ceri/ART\%20FOR\%2O ART\%E2\%80\%99S\%20SAKE\%20OVERVIEW_EN_R3.pdf 


\section{Biographical note}

IRENA LeSAR, Associate professor, is teaching and researching at the Faculty of Education and Academy of Music, University of Ljubljana. She completed her Honours Degree in Pedagogy and Sociology of Culture (1998), Master of Science (2002) and received her Doctor of Science in Education (2007) at University of Ljubljana, Faculty of Arts. In the last decade her research is focused on the conceptualization of justice and inclusion, the status of various marginalized groups, in particular Roma, (new) immigrants and SEN students in Slovenian schools through their social participation and academic achievement. So far has alone or in co-authorship published five books and 37 scientific papers. 